\title{
Family Members Can be Valuable Mentors
}

\section{Kimberly Eddleston (Northeastern University)}

\section{KEYWORDS: Entrepreneurship, Family Business,}

Women.

Entrepreneur, philanthropist and author Simran Mohinani has great role models among her family members, who run Platinum Estates, a thriving enterprise in Europe. Mohinani has three of her own ventures -- the latest is Mohlia(https://www.mohlia.shop) , which delivers lifelike preserved roses that last far longer than regular fresh flowers. But she continues to be a stakeholder in the family business and to learn from her relatives, especially her father, who has been her mentor. Here she talks about how her family's experiences and networks have helped her become a better entrepreneur, and how she manages being both a daughter and a mentee. She also shares her advice for future family business leaders and for all women who aspire to be entrepreneurs. 